\title{
ANALISIS KESIAPAN IMPLEMENTASI E-GOVERNMENT PADA DIREKTORAT JENDERAL PENYELENGGARAAN HAJI DAN UMRAH KEMENTERIAN AGAMA REPUBLIK INDONESIA
}

\author{
Sarika Afrizal ${ }^{1}$, Nashrul Hakiem ${ }^{1}$, dan Dana Indra Sensuse ${ }^{2}$ \\ ${ }^{1}$ Department of Informatics, Faculty of Science and Technology, UIN Syarif Hidayatullah Jakarta, \\ Indonesia \\ ${ }^{2}$ E-government Lab, Faculty of Computer Science, Universitas Indonesia \\ E-mail: sarika.afrizal@gmail.com
}

\begin{abstract}
Implementation of e-government is currently an innovation that every developing country is expected to achieve. Due to the rapid growth of information and communication technology, establishing a good government is what people expect the most. The President has released a Presidential Instruction No. 3 Year 2003 on National Policy and Strategy Development of e-government that obligate all the government institutions in Indonesia to immediately implement the e-government in order to improve the efficiency, effectiveness, transparency, and the accountability in governance. This study proposes the readiness factor in the implementation of e-government in the Ministry of Religion in Indonesia through indicators assessed by the experts in e-government field. In this study the indicators based on dimensions are classified as follow: Technological Dimension, Organizational Dimension, Environmental Dimension, and People Dimension (user or human resource).
\end{abstract}

Keywords: Readiness Factor, e-Government, Analytical Hierarchy Process, Ministry of Religious Affair, Hajj, Umrah.

\begin{abstract}
Abstrak
Implementasi e-government merupakan suatu bentuk perubahan baru yang diharapkan dari sebuah negara yang berkembang. Karena semakin berkembangnya informasi dan semakin pesatnya kemajuan TIK, perubahan untuk menjadi good government sangat diharapkan masyarakat. Presiden sebagai pemberi mandat mengeluarkan Instruksi Presiden Nomer 3 Tahun 2003 tentang Kebijakan dan Strategi Nasional Pengembangan e-government kepada seluruh lembaga-lembaga di seluruh pemerintahan di Indonesia untuk segera mengimplementasikan e-government guna meningkatkan efisiensi, efektifitas, transparansi, dan akuntabilitas dalam penyelenggaraan pemerintahan. Penelitian ini mengajukan faktor kesiapan dalam implementasi e-government pada Kementerian Agama yang ada di Indonesia melalui indikator-indikator yang dinilai oleh para ahli di bidang e-government. Pada pe-nelitian ini indikator-indikator tersebut dikelompokkan berdasarkan dimensi-dimensinya di antaranya ialah Dimensi Teknologi, Dimensi Organisasi, Dimensi Lingkungan, dan Dimensi Orang (Pengguna atau Sumber Daya Manusia).
\end{abstract}

Kata Kunci: Faktor Kesiapan, e-Government, Analytical Hierarchy Process, Kementerian Agama, Siskohat, Haji, Umroh.

\section{Pendahuluan}

Indonesia yang tergolong negara berkembang satu dasawarsa ini menunjukkan peningkatan dalam penggunaan internet. Walaupun belum menyamai negara-negara maju lainnya, tetapi hal ini sudah dapat menggambarkan bahwa Indonesia sudah siap untuk beralih menuju pada penerapan e-government. Implementasi e-government merupakan suatu bentuk perubahan baru yang diharapkan dari sebuah negara yang berkembang. Karena semakin berkembangnya informasi dan semakin pesatnya kemajuan TIK, perubahan untuk menjadi good government sangat diharapkan masyarakat. Masyarakat sangat optimis dengan adanya $e$ government yang nantinya diharapkan menimbulkan dampak perubahan ke arah yang lebih baik bagi pelayanan dalam pemerintahan [1].

Bentuk implementasi e-government di setiap negara berbeda-beda disesuaikan dengan kondisi peraturan yang mengatur jalannya pemerintahan di suatu negara tersebut. Kondisi $e$ government dipengaruhi juga oleh faktor internal dan eksternal masing-masing negara. Hal lain yang berpengaruh adalah budaya, pendidik- 
an, pandangan politik dan kondisi perekonomian. Visi, misi dan strategi dari sebuah negara yang mengimplementasikan e-government juga dapat mempengaruhi bentuk dari e-government itu nantinya.

Saat ini, sebanyak 53,6\% lem-baga pemerintahan di Indonesia termasuk Kementerian sudah menyediakan situs resmi yang menyediakan informasi mengenai pemerintahan [2]. Namun, belum banyaknya referensi tentang e-government di dalam Kementerian memunculkan sebuah pertanyaan besar, "Apakah pelaksanaan Instruksi Presiden telah dijalankan dengan benar?" Alasannya adalah karena tujuan e-government itu sendiri adalah membuat transaksi yang ada di pemerintahan menjadi lebih transparan. Hingga tahun 2011 pelaksanaan e-government masih sangat lambat. Terlihat dari banyaknya data yang telah tersimpan di beberapa instansi pemerintahan yang tidak dapat digunakan atau dimanfaatkan oleh instansi pemerintahan lainnya.

Perkembangan regulasi peraturan pemerintah mengenai e-government juga terbilang sangat lambat. Hal ini terbuktikan dengan tidakadanya perubahan signifikan sebagai luaran dari penerapan Instruksi Presiden Nomer 3 Tahun 2003 tentang Kebijakan dan Strategi Nasional Pengembangan e-government. Peraturan tentang e-government lebih banyak terjadi di masingmasing instansi terkait yang melakukan implementasi e-government tersebut. Sehingga banyak implementasi e-government yang kurang bisa dirasakan secara langsung oleh masyarakat. Peraturan perundang-undangan tentang pelayanan publik Nomor 14 Tahun 2008 tentang Keterbukaan Informasi Publik merupakan dukungan teknis dalam mencapai good governance yang mendukung Instruksi Presiden dalam mencapai pelayanan publik yang transparan, efektif, efisien, akunta-bel serta dapat dipertanggungjawabkan.

Untuk mencapai tujuan pemerintah tersebut, perlu dilihat sampai sejauh mana perkembangan e-government yang ada di Indonesia saat ini terutama pada tingkat Kementerian. Oleh karena itu dibutuhkan sebuah model yang dapat mewakili nilai-nilai pencapaian good government tersebut. Model dibagi berdasarkan komponen penting yang mempengaruhi setiap sisi layanan publik. Pengelompokan komponen dihitung secara kuantitatif berdasarkan nilai tingkat kesetujuannya. Nilai dari kedekatan tersebut didapat dari seorang para pada bidang e-government dengan melakukan wawancara dan mengisi kuisioner. Selanjutnya dilakukan analisis terhadap data dan masukan yang didapat. Setelah dilakukan analisis dan perhitungan tingkat kesepakatan, maka akan terbentuk model, dari mo- del yang terbentuk tersebut kemudian diujicobakan pengukurannya. Model yang terbentuk akan diukur berdasarkan sisi internal dari Kementerian Agama pada bagian Direktorat Penyelenggaraan Haji dan Umrah. Komponen-komponen yang telah didapat kemudian dinilai untuk menentukan tingkatan kesiapan yang telah dicapai dengan metode AHP (Analy-tical Hierarchy Process) [3] yang nantinya akan dapat mengukur kesiapan implementasi e-go-vernment yang ada pada Kementerian Agama tersebut. Dengan AHP akan didapat data yang kuantitaf, sehingga dapat memudahkan mem-persentasekannya.

\section{Metode Penelitian}

Tahapan penelitian ditunjukkan pada Gambar 1 dan dijabarkan secara berurutan sebagai berikut:

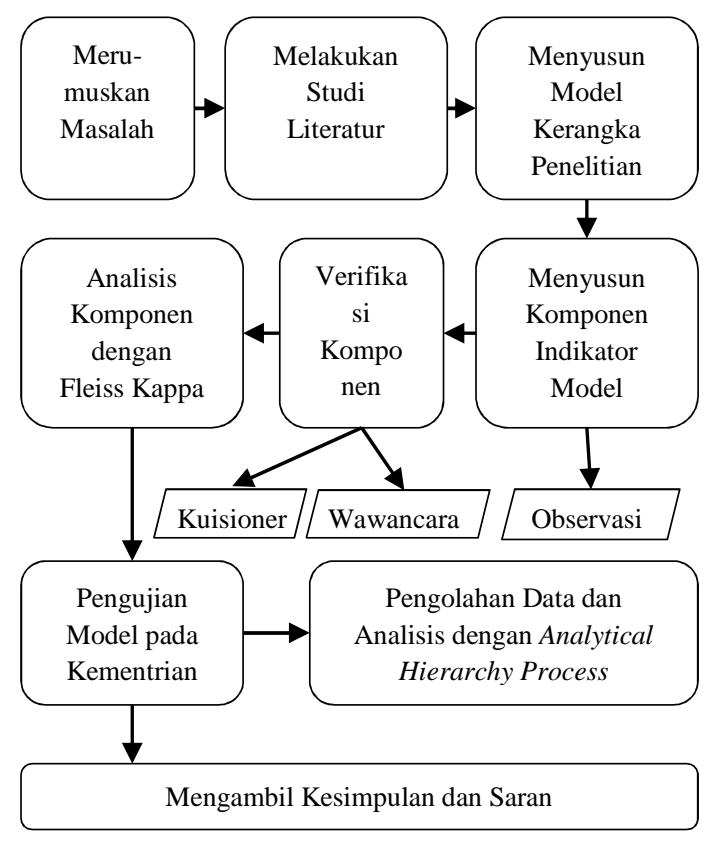

Gambar 1. Tahapan pada penelitian

\section{Merumuskan Masalah}

Pada tahapan ini permasalahan yang akan diteliti dicari dan ditetapkan untuk kemudian pertanyaan penelitian (research question) dirumuskan. Rumusan pertanyaan ini merupakan gambaran dari hasil yang ingin dicapai dan dijawab pada akhir penelitian.

\section{Melakukan Studi Literatur}

Mencari referensi-referensi yang relevan dengan objek yang akan diteliti. Pencarian referensi dilakukan di perpustakaan, toko buku, maupun secara online melalui internet. Melakukan pencarian data-data sekunder yang terkait dengan masalah e-government, regulasi yang 
mengatur e-government serta tentang metode untuk pengolahan data. Setelah mendapatkan referensi-referensi yang relevan tersebut, kemudian mencari informasi-informasi yang dibutuhkan dalam penelitian ini dari referensi-referensi tersebut. Informasi yang didapatkan digunakan dalam penyusunan landasan teori, serta penentuan kerangka yang komponen-komponennya dapat mengukur kesiapan implementasi $e$ government.

\section{Menyusun Model Kerangka Penelitian}

Melakukan penyusunan model kerangka penelitian untuk pengerjaan tahapan penelitian. Model kerangka yang didapatkan berdasarkan literatur yang dibaca dari beberapa penilitian. Penyusunan model kerangka penelitian ini berguna untuk proses pengerjaan penelitian agar tetap terkonsep dengan jelas dan baik.

\section{Menyusun Komponen Indikator Model}

Menentukan komponen yang akan menjadi kompetensi. Kerangka-kerang tersebut awalnya ditentukan berdasarkan studi literatur sejenis kemudian dilakukan observasi langsung dengan mengamati jalannya implementasi e-government pada sistem pemerintahan. Pengamatan langsung penerapan e-government pada pemerintahan dilakukan baik dari segi infrastruktur dan juga sumber daya manusia. Hal ini sangat dibutuhkan agar didapat analisa terhadap komponen yang akan diusulkan.

\section{Verifikasi Komponen Indikator Model}

Komponen yang telah ditentukan kemudian di uji tingkat kesepakatan dengan menggunakan metode tingkat kesepakatan. Pengukuran dilakukan dengan wawancara dan kuesioner dengan mengisi kuisioner oleh orang yang expert dibidang e-government. Expert yang dimaksud adalah orang yang paham tentang e-government. Pihak expert ditentukan berdasarkan dari kalangan pendidik dan kalangan praktisi yang ada dilapangan.

\section{Analisis Komponen dengan Fleiss Kappa}

Setelah mendapatkan data kuesioner dari pihak pakar kemudian dilakukan penganalisisan data menggunakan Fleiss Kappa [4][5]. Tujuannya menggunakan Fleiss Kappa ini untuk mendapatkan indikator dan kerangka model yang tepat setelah diberi penilaian oleh pihak expert tersebut. Setelah mendapatkan hasil dari pengolahan dan analisis data, kemudian didapat perkiraan, faktor-faktor apa saja atau komponen apa saja yang dapat menjadi kerangka atau alat ukur untuk mengukur kesiapan implementasi $e$ government pada Kementerian Agama yang ada di Indonesia. Hasil kerangka model ini yang nanti akan diujicobakan.

\section{Pengujian Model pada Kementerian}

Setelah mendapatkan komponen indikator tersebut, dilakukan pengujian pada Kementerian Agama. Departemen yang akan diujikan merupakan bagian atau divisi yang mengelola $e$-government itu sendiri sehingga mereka dapat menilai subtansi dari setiap komponen indikator yang diajukan.

\section{Pengolahan Data dan Analisis dengan Analytical Hierarchy Process}

Setelah melakukan pengujian kemudian dilakukan pengolahan data menggunakan Analytical Hierarchy Process atau AHP. Metode ini mengukur tingkat perasaan dari setiap pegawai pada Kementerian Agama khususnya Direktorat SISKOHAT terhadap substansi komponen indikator yang diajukan.

\section{Mengambil Kesimpulan dan Saran}

Mengambil kesimpulan atas hasil dari pengujian dan hasil analisis terhadap model yang dihasilkan. Kemudian memberikan saran atas kesimpulan yang didapatkan dan memberikan masukan untuk penelitian berikutnya apabila dikerjakan atau dilanjutkan.

\section{Analisis dan Hasil}

Pada bagian ini dijelaskan proses perancangan kerangka kerja pengukuran tingkat kesiapan implementasi e-government. Penjelasan meliputi hasil kuesioner dengan expert, analisis kesepakatan, dan analisis dengan AHP.

Hasil akhir dari Fleiss Kappa pada Tabel 1 menentukan faktor yang akan digunakan dalam mengukur kesiapan e-government yang akan dilakukan di tahap selanjutnya. Pengambilan faktor ini dilakukan dengan melihat hasil akhir kappa. Nilai kappa yang didapat kemudian dibandingkan dengan nilai interpretasi yang telah ditentukan oleh [6] dimana dari hasil Tabel 2 didapat nilai kappa 0.4099 yang menggunakan pembulatan ke atas 0.41 sehingga tercapai interpretasi Moderate Agreement atau tingkat kesepakatan yang sedang atau berada di tengah. Namun, dengan pertimbangan dari para pakar bahwa faktor ekonomi pada kategori environment bukanlah faktor yang dapat mengukur kesiapan dalam implementasi e-government dan tidak berdampak langsung pada sebuah kementerian pada khususnya maka fak-tor tidak digunakan dalam pengukuran kesiapan. Dengan alasan karena nilai kesepakatan pada faktor tersebut dominan tidak menyetujui penggunaan 
faktor tersebut, akhirnya didapat model akhir untuk penelitian ini.

TABEL 1

HASIL PERHITUNGAN DENGAN FLEISS KAPPA

\begin{tabular}{|c|c|c|c|}
\hline Kategori & Faktor & p.1 & p.2 \\
\hline \multirow[t]{6}{*}{ Teknologi } & \multirow{2}{*}{$\begin{array}{l}\text { Kolaborasi dan } \\
\text { terintegrasi }\end{array}$} & 0 & 4 \\
\hline & & 0 & 4 \\
\hline & \multirow[t]{2}{*}{ Keamanan \& Privasi } & 0 & 4 \\
\hline & & 0 & 4 \\
\hline & \multirow[t]{2}{*}{ Disaster Recovery } & 1 & 3 \\
\hline & & 0 & 4 \\
\hline \multirow[t]{12}{*}{ Organisasi } & \multirow{2}{*}{$\begin{array}{l}\text { Visi, misi dan strategi } \\
\text { organisasi }\end{array}$} & 0 & 4 \\
\hline & & 0 & 4 \\
\hline & \multirow{2}{*}{$\begin{array}{l}\text { Dukungan Top } \\
\text { Manajemen }\end{array}$} & 0 & 4 \\
\hline & & 0 & 4 \\
\hline & \multirow[t]{2}{*}{ Pelatihan Pegawai } & 0 & 4 \\
\hline & & 0 & 4 \\
\hline & \multirow{4}{*}{$\begin{array}{l}\text { Budged \& Time } \\
\text { (Pendanaan \& } \\
\text { Waktu) } \\
\text { Peraturan dan } \\
\text { kebijakan }\end{array}$} & 0 & 4 \\
\hline & & 0 & 4 \\
\hline & & 0 & 4 \\
\hline & & 0 & 4 \\
\hline & \multirow[t]{2}{*}{ Dokumentasi } & 2 & 2 \\
\hline & & 0 & 4 \\
\hline \multirow{6}{*}{$\begin{array}{l}\text { Environ- } \\
\text { ment }\end{array}$} & \multirow[t]{2}{*}{ Ekonomi } & 3 & 1 \\
\hline & & 3 & 1 \\
\hline & \multirow[t]{2}{*}{ Budaya Sosial } & 0 & 4 \\
\hline & & 0 & 4 \\
\hline & \multirow[t]{2}{*}{ Awarness } & 0 & 4 \\
\hline & & 1 & 3 \\
\hline \multirow[t]{2}{*}{ People } & \multirow{2}{*}{$\begin{array}{l}\text { Kemampuan Staf } \\
\text { dengan Teknologi } \\
\text { Staff teknis }\end{array}$} & 0 & 4 \\
\hline & & 0 & 4 \\
\hline Total & 26 & 0.096 & 0.904 \\
\hline
\end{tabular}

Dari Tabel 3 terlihat nilai Inconsistency ialah 0.04. Dengan demikian, perbandingan tersebut dapat diterima tanpa harus diulang perbandingannya karena nilai inconsistency yang masih aman.

TABEL 2

\begin{tabular}{lc}
\multicolumn{2}{c}{ HASIL KAPPA } \\
\hline Ket & Nilai \\
\hline Po (proporsi kesepakatan yang diamati) & 0.897436 \\
Pe (proporsi kesepakatan yang diharapkan) & 0.826183 \\
Kappa & 0.409929 \\
\hline
\end{tabular}

Dari hasil yang tertera pada Tabel 4 maka dapat disimpulkan bahwa indikator yang memiliki nilai tertinggi yaitu Teknologi Informasi Infrastruktur dengan bobot 0.117 , kemudian diikuti oleh indikator Peraturan dan Kebijakan dengan bobot 0.110 sedangkan untuk bobot terkecil yaitu Budaya Sosial dengan 0.022.
TABEL 3

HASIL MODEL SETELAH DIUKUR

\begin{tabular}{|c|c|}
\hline Dimensi & Indikator \\
\hline Teknologi & $\begin{array}{l}\text { Kolaborasi dan sistem yang } \\
\text { terintegrasi } \\
\text { Keamanan \& Privasi } \\
\text { Teknologi Informasi Infrastruktur } \\
\text { Disaster Recovery }\end{array}$ \\
\hline Organisasi & $\begin{array}{l}\text { Visi, Misi \& Strategi } \\
\text { Dukungan Top Manajemen } \\
\text { Pelatihan Pegawai } \\
\text { Budged (Pendanaan) \& Time } \\
\text { Peraturan dan Kebijakan } \\
\text { Dokumentasi }\end{array}$ \\
\hline $\begin{array}{l}\text { Environtment } \\
\text { (Lingkungan) }\end{array}$ & $\begin{array}{l}\text { Budaya Sosial } \\
\text { Legalitas } \\
\text { Awareness }\end{array}$ \\
\hline $\begin{array}{l}\text { People } \\
\text { (Pengguna } \\
\text { atau SDM) }\end{array}$ & $\begin{array}{l}\text { Kemampuan Staf dengan teknologi } \\
\text { Staf teknis }\end{array}$ \\
\hline
\end{tabular}

Dari hasil pada Table 4 dapat diambil kesimpulan bahwa kondisi infrastruktur pada kementerian Agama sangatlah baik dibandingkan indikator yang lain, namun indikator budaya sosial sangatlah rendah. Hal ini menunjukkan kondisi perubahan dari sistem tradisional menuju kondisi online dianggap tidak tersosialisasikan kepada masyarakat dengan baik oleh Kementerian Agama.

TABEL 4.

HASIL AHP KEMENTERIAN AGAMA

\begin{tabular}{|c|c|c|c|}
\hline Kategori & Faktor & $\begin{array}{l}\text { Bobot } \\
\text { Faktor }\end{array}$ & $\begin{array}{l}\text { Bobot } \\
\text { Kate- } \\
\text { gori }\end{array}$ \\
\hline \multirow[t]{5}{*}{ Teknologi } & $\begin{array}{l}\text { Kolaborasi dan Sistem } \\
\text { yang Terintegrasi }\end{array}$ & 0.060 & 0.357 \\
\hline & Keamanan dan Privasi & 0.103 & \\
\hline & Teknologi Informasi & 0.117 & \\
\hline & Infrastruktur & & \\
\hline & Disaster Recovery & 0.077 & \\
\hline \multirow[t]{8}{*}{ Organisasi } & Visi,misi dan Strategi & 0.040 & 0.405 \\
\hline & Dukungan Top & 0.042 & \\
\hline & Manajemen & & \\
\hline & Pelatihan Pegawai & 0.051 & \\
\hline & $\begin{array}{l}\text { Pendanaan dan Waktu } \\
\text { (Budged \& Time) }\end{array}$ & 0.059 & \\
\hline & Peraturan dan & 0.110 & \\
\hline & Kebijakan & & \\
\hline & Dokumentasi & 0.103 & \\
\hline \multirow{3}{*}{$\begin{array}{l}\text { Environ- } \\
\text { ment }\end{array}$} & Budaya Sosial & 0.022 & 0.134 \\
\hline & Awarness & 0.051 & \\
\hline & Legalitas & 0.061 & \\
\hline \multirow[t]{2}{*}{ People } & $\begin{array}{l}\text { Kemampuan Staf } \\
\text { dengan Teknologi }\end{array}$ & 0.045 & 0.106 \\
\hline & Staf Teknis & 0.061 & \\
\hline
\end{tabular}

\section{Kesimpulan dan Saran}

Penelitian ini bertujuan untuk menentukan indikator dalam mengukur kesiapan implementasi e-government pada Kementerian Agama, dan mengukur tingkat kesiapan e-government 
pada Kementerian Agama. Penelitian ini mengusulkan sebuah model yang terdiri indikatorindikator yang penilaiannya menggunakan teknik measurement agreement dengan Fleiss Kappa, yang diukur oleh empat orang expert. Indikator-indikator ini disusun berdasarkan teknik AHP, yaitu pengelompokkan indikator secara homogen. Kategori indikator dalam penelitian ini ditentukan berdasarkan literatur yang kemudian disesuaikan dengan keadaan di Indonesia. Kategori yang paling banyak diteliti sebelumnya adalah Organisasi dan Teknologi kemudian pada beberapa literatur Environment (Lingkungan) dan People (Pengguna atau SDM) merupakan kategori yang berpengaruh, kemudian disesuai kategorinya pada penelitian ini. Setelah itu dilakukan pengujian dengan empat orang expert untuk mengukur tingkat kesepakatan me-reka atas model yang diusulkan.

Pencarian nilai kese-pakatan tersebut menggunakan Fleiss Kappa. Hasil nilai untuk model pada penelitian ini ada-lah 0,41 , berada pada peringkat sedang. Dari hasil sebaran data didapat 15 indikator yang dapat dijadikan sebuah model dari 22 indikator yang diusulkan. Kategori umum yang ditentu-kan adalah Teknologi, Organisasi, Environment (Lingkungan), People (Pengguna atau SDM). Indikator yang menjadi model untuk mengukur kesiapan implementasi e-government pada Ke-menterian adalah Kolaborasi dan Sistem yang terintegrasi, Keamanan dan Privasi, Tek-nologi Informasi Infrastruktur dan Disaster Recovery terdapat pada kategori Teknologi. Pada kategori Organisasi yaitu visi, misi dan stategi organisasi, dukungan top manajemen, pelatihan pegawai, pendanaan dan waktu (budget and time), peraturan dan kebijakan, dan dokumentasi. Pada environment (lingkungan), terdapat budaya sosial, legalitas dan awarness. Terakhir pada kategori people (pengguna atau SDM), terdapat kategori Kemampuan staf dengan teknologi dan staf teknis.

Setelah model sudah dapat ditentukan, penelitian dilanjutkan dengan pengujian model tersebut pada Kementerian yang ada menggunakan metode Decission Support System dengan kuesioner AHP yang disebarkan pada Kementerian Agama dengan 33 kuisioner. Data kemudian diolah menggunakan bantuan software $E x$ pert Choice.

Untuk penelitian selanjutnya diharapkan dalam penetuan dan pemilihan model yang diusulkan dapat menggunakan metode yang berbeda dalam menganalisis dan kemudian dalam pemilihan jumlah sampel baik dari segi $e x-$ pert ataupun dari kementerian pada penelitian selanjutnya dapat menggunakan responden yang lebih banyak sehingga menghasilkan angka perhitungan pada data yang lebih baik.

\section{Penghargaan}

Penelitian ini didanai oleh UIN Syarif Hidayatullah Jakarta berdasarkan Keputusan Kuasa Pengguna Anggaran UIN Syarif Hidayatullah Jakarta Nomor: Un.01/KPA/279/2015 urut 207 Tanggal 27 Mei 2015.

\section{Referensi}

[1] R. Heeks, Implementing and Managing eGovernment : An International Text. London: SAGE Publications Ltd, 2006.

[2] P. W. Handayani and N. P. Kardia, "Analisis Tingkat Implementasi E-government pada Level Kementerian Indonesia Berdasarkan Framework Deloitte \& Touche," J. Sist. Inf., vol. 6, no. 2, pp. 134-139, 2010.

[3] F. Zahedi, "The Analytic Hierarchy Process-A Survey of the Method and its Applications," Interfaces (Providence), vol. 16, no. 4, pp. 96-108, Aug. 1986.

[4] J. L. Fleiss, J. Cohen, and B. S. Everitt, "Large Sample Standard Errors of Kappa and Weighted Kappa," Psychol. Bull., vol. 72, no. 5, pp. 323-327, 1969.

[5] J. L. Fleiss, B. Levin, and M. C. Paik, Statistical Methods for Rates and Proportions. New Jersey: John Wiley \& Sons, 2013.

[6] J. R. Landis and G. G. Koch, "The Measurement of Observer Agreement for Categorical Data," Biometrics, vol. 33, no. 1, pp. 159-174, 1977. 